\title{
Stressors in patients admitted to adult intensive care units
}

\author{
Factores estresores en pacientes en unidades de cuidado intensivo adulto \\ Fatores de stresse em pacientes em unidades de cuidados intensivos de adultos
}

Diana Carolina Bernal Ruiz*; Renata Virginia González Consuegra**; Ingrid Tatiana Rojas Ruiz***

\begin{abstract}
Background: Intensive care units (ICU) are stress-generating settings given the environment and the biomedical approach that is practiced there.

Objectives: To identify the perception and level of stress that the situations that occur in the ICU generate on the patients and determine the sociodemographic characteristics influencing stress.

Methodology: Observational, cross-sectional study with an analytical approach in which the Escala de Factores Estresantes Experimentados por los Pacientes en UCI was applied.

Results: In this sample, $13 \%$ of respondents had a moderate or high level of stress. The most stressful situations included being concerned about their health and its consequences, not being able to go to the bathroom, not being able to fulfill their rolein thefamily, not having control over their activities, and feeling pain. The analysis of the sociodemographicdatashowed that education $(p=0.028)$ : basic $(p=0.028 ; \mathrm{OR}=16)$ and university $(p=0.027 ; \mathrm{OR}=17)$ influenced the level of stress. Conclusion: For most of the interviewees, ICU stay was not stressful or mildly stressful. The educational level predisposes to stress perception. The most stressful situations are emotional situations.
\end{abstract}

Keywords: critical care; intensive care units; critical illness; stress, psychological; stress, physiological; risk factors

\section{Resumen}

Marco contextual: Las unidades de cuidado intensivo (UCI) son áreas consideradas generadoras de estrés dado el entorno y el enfoque biomédico que allí se practica.

Objetivos: Identificar la percepción y el nivel de estrés que las situaciones que ocurren en las UCI generan sobre los pacientes y determinar las características sociodemográficas influyentes.

Metodología: Estudio observacional, de corte trasversal, con intencionalidad analítica. Se aplicó la Escala de Factores Estresantes Experimentados por los pacientes en la UCI.

Resultados: El 13\% de los entrevistados expresaron un nivel moderado o alto de estrés. Tener preocupaciones por su salud y las repercusiones de esta, no poder ir al baño, no poder cumplir con su papel en la familia, no tener control de sus actividades y sentir dolor son las situaciones más estresoras. De los datos sociodemográficos, la escolaridad $(p=0,028)$ : primaria $(p=0,028 ; \mathrm{OR}=16)$ y universitario $(p=0,027 ; \mathrm{OR}=17)$ resultaron influyentes. Conclusión: Para la mayoría de los entrevistados la estancia en la UCI resultó poco o nada estresante. El nivel educativo predispone la percepción del estrés. Las situaciones más estresoras son las emocionales.

Palabras clave: cuidados críticos; unidades de cuidados intensivos; enfermedad crítica; estrés psicológico; estrés fisiológico; factores de riesgo

\footnotetext{
*MSc., RN specialized in hemodynamics, National University of Columbia, 111321, Bogotá, Colombia [dcbernalr@unal.edu.co].Contribution to the article: literature search for the introduction an contextul framerk, design of the research question and methodology: data collection, organiztion, and analysis; proposal of the discussion and conclusion. tion, and analysis; proposal of the discussion and conclusion.
**Ph.D., RN, Full Professor, National University of Columbia, 111321, Bogotá, Colombia [rvgonzalezc@unal.edu.co].Contribution to the article: guided the literature search process; collaborated in the planning and organization of the methodology; supervised data collection; contributed to the the planning and organ.

****MSc., Full Professor, Cafam University Foundation, 111211, Bogotá, Colombia [tatianarojasruiz@ gmail.com]. Contribution to the article: proposal and organization of methodology; performed the statistical analysis; participated in the discussion and conclusions.
}

\section{Resumo}

Enquadramento: As unidades de cuidado intensivo (UCI) são consideradas geradoras de stresse dado o ambiente e a abordagem biomédica que ali se pratica. Objectivos: Identificar a perceção e o nível de stresse que as situaçóes que ocorrem nas UCI geram nos pacientes e determinar as características sociodemográficas que o influenciam.

Metodologia: Estudo observacional, de corte transversal, com intencionalidade analítica, onde foi aplicada a Escala de Factores Estresantes Experimentados por los Pacientes en UCI.

Resultados: Treze por cento dos entrevistados expressaram um nível moderado ou elevado de stresse. Apresentam preocupações sobre a sua saúde e o impacto desta, não poder ir à casa de banho, não ser capaz de cumprir o seu papel na família, não ter controlo das suas atividades e dor são as situaçóes mais stressantes. Dos dados sociodemográficos, escolaridade $(p=0,028)$ : primária $(p=0,028 ; \mathrm{OR}=16)$ e universidade ( $p=0,027$; OR $=17$ ), foram influentes.

Conclusáo: Para a maioria dos entrevistados a permanência na UCI foi pouco ou nada stressante. O nível de escolaridade explica a perceção do stresse. As situações mais stressoras sao as emocionais.

Palavras-chave: cuidados críticos; unidades de terapia intensiva; estado terminal; estresse psicológico; estresse fisiológico; fatores de risco 


\section{Introduction}

Intensive care units (ICU) are stress-generating areas. When patients are admitted to the ICU, they are likely to experience stress (Chamorro \& Romera, 2015; Olausson, Lindahl, \& Ekebergh, 2013) because of stress-inducing stimuli, such as the admission to a place which poses a vital threat and feeling close to death given the complexity of the health-disease process. In addition, the high degree of care instrumentalization, the more complex environment, the abundance of technological elements, the use of medication that may affect mental clarity and focus (Guttormson, 2014). The lack of leisure activities, the monotonous environment, and the similar care routines every day. The interruption of daily and circadian rhythms. The establishment of new schedules, the separation from personal belongings, from loved ones, from family, and common interactions (work, home).

In the ICU, there is a subordination to one's own body, associated activities, and basic needs. Loss of autonomy is tangible, as well as the adoption of a passive role, the submission to procedures that violate privacy (being undressed, constantly exposing the body, doing frequent physical examinations; Baggio, Pomatti, Bettinelli, \& Erdmann, 2011), and the continuous exposure to sounds, smells, artificial lighting, and examinations that may cause pain, affect sleep, mobility, and the ability to communicate and eat.

It has been demonstrated that both stressors and stress can jeopardize the patient's well-being comfort (Jutte, Erb, \& Jackson, 2015) and lead to harmful psychophysiological responses that hinder recovery (Parker et al., 2015). The aim of this study was to identify patients' perception and level of stress as a result of environmental, emotional, sensory, and communication situations at ICU (Escala de Factores Estresantes Experimentados por los Pacientes en UCI), as well as to determine the sociodemographic characteristics influencing stress.

\section{Background}

Stress is an adaptive response of the body to a situation that is considered as exceptional, threatening or overflowing in resources. Ac- cording to the literature, stress is a response, incentive or interaction (Rom \& Reznick, 2016), depending on the emphasis on its elements.

The notion of stress as a response begins in 1936 with the studies of Hans Selye and John Manson, who considered it as the sum of all stereotyped reactions that occur as a result of any demanding task or demand on the body, namely a biochemical process of responses mediated by the hypothalamic-pituitary-adrenal axis and other hormones whose purpose is to maintain life and adapt to the changing external influences.

In 1979, Thomas Holmes and Richard Rahe proposed the theory of critical life events which considers stress as a stimulus, something external causing tension. This theory argues that life events are those individual experiences capable of producing unusual or extraordinary physiological or psychological reactions. They are considered stressful life events depending on the amount of change that they entail on habits and behaviors.

Finally, in 1986, in their Transactional Model, Richard Lazarus and Susan Folkman argue that stress is an interaction. In this model, stress is seen as a process of adaptation to an environment that is potentially dangerous. Its occurrence will depend on the individuals' perception of the situations based on their age, education, gender, ethnicity, religion, goals, values, experiences, and available coping resources.

The occurrence of stress depends on the existence of stressors or causes of stress. Stress requires stressors or causes of stress, which are the terms under which any element, situation or stimulus, due to its uncontrollability, change or lack of knowledge, is able to generate stress. According to Orlandini (1999), stressors can be divided according to the moment in which they happen (remote, recent, present, future), the period in which they happen, the number of stressors (one or multiple), the intensity of their impact (micro-stressors, moderate or intense stressors); the nature of the agent (physical, chemical, physiological, intellectual, psychosocial), the topic (family, occupational, marital, economic), the reality of the stimulus (real, representation, imaginary), and the location of the 
demand (exogenous or environmental, endogenous, intrapsychic).

Regardless of its conceptualization, the World Health Organization (ICD-10. 2010 Classification of Mental and Behavioural Disorders) and the American Psychiatric Association (DSM IV-TR. 2013. Diagnostic and Statistical Manual of Mental Disorders) recognize that stress can act as a mechanism that keeps the mind alert, focused, and energetic (allostasis). However, it is also an intense demand that produces responses exceeding the body's resistance, hampering health, and leading to the development of disorders such as hypertension, arrhythmia, hypoperfusion, hyperglycemia, hyperlactatemia, predisposition to infection, gastric ulcer, increased perception of pain, insomnia, irritability, depression, anxiety, fear, melancholy, fatigue, among others, which are similar to or worsen a disease, making it necessary to treat and prevent stress (Elliott et al., 2014).

\section{Research questions}

What were the most stressful situations at the ICU from the perspective of adult patients? What is the level of stress of ICU patients? What are the sociodemographic factors associated with perceived stress in ICU adult patients?

\section{Methodology}

An observational, cross-sectional study was conducted with an analytical approach between January 2014 and January 2015. The sample was composed of 353 patients from three ICU of a fourth level health institution. Patients were selected by convenience consecutively as cases arrived. The number was calculated based on the percentage of people hospitalized in those ICU every year, a maximum margin of error of $5 \%$, and assuming an infinite population. $\mathrm{Pa}-$ tients with a minimum of 24 hours of stay at the ICU, aged 18 years or over, level of consciousness - orientated (assessed using a Glasgow scale of 15/15), and without communication difficulties were included. Patients who did not understand or speak Spanish and had delirium and/or a disease with neurological impairment were excluded.

Data were collected using an individual structured interview at discharge if the patient was discharged home, at day 1 or 2 if he/she was hospitalized, and at day 3 , in only a few cases, if the patient was discharged on weekends. A sociodemographic questionnaire was designed by the authors to assess age, gender, marital status, education level, professional situation, number of dependents, duration of hospitalization, type of social security Health Promotion Entity (Empresa Promotora de Salud - EPS): hospital stay with coverage of basic health requirements coverage thanks to those who are able to pay. Subsidized Scheme Administrator (Administradora del Régimen Subsidiado-ARS): hospital stay with coverage of basic health requirements thanks to a subsidized system for those who are vulnerable and unable to pay. Prepaid Medicine (Medicina Prepagada): hospital stay with coverage of basic health requirements and quotation for a supplementary scheme improving the hotel services), as well as the type of hospitalization (urgent: the patient does not know what the ICU is; planned: the patient was previously explained about the purpose of his/her stay at the ICU).

Stress was identified using the Escala de Factores Estresantes Experimentados por los Pacientes en UCI. This scale was validated for the Colombian context and has facial validity: simple agreement coefficient $>0.8$; content validity: Lawshe's modified index > 0.58; Cronbach's alpha of 0.877 ; Spearman's coefficient of 0.811; Guttman's coefficient of 0.810 (Bernal Ruiz \& González Consuegra, 2016). This instrument is composed of 45 stressful situations (environmental, emotional, sensory, and communication) rated on a Likert-type scale ranging from 1: not stressful, 2: mildly stressful, 3: moderately stressful, to 4: very stressful. Therefore, the maximum score is 180 and the minimum score is 45 . Nevertheless, the minimum score could be even less if the stressors that did not apply to the patient's situation were excluded. At the end of the scale, patients could make relevant comments.

Statistical analysis was performed using Microsoft Excel and IBM SPSS Statistics, ver- 
sion 17.0. The qualitative variables are reported as percentages and the quantitative variables as means and standard deviations. The bivariate analysis was performed using the chi-square test to establish the difference in percentages for qualitative variables. The Student's t-test was used to determine the significant difference in quantitative variables. With regard to multivariate analysis, a binary logistic regression was performed to calculate statistical significance and odds ratio (OR) because it is a dichotomous outcome involving both qualitative and quantitative variables and a method that allows establishing explanatory and predictive models. The study took into account the existing ethical guidelines for clinical research involving human beings. It was approved by the ethics and research committee of the health institution where it was conducted. Participants signed an informed consent form.

\section{Results}

Participants had a mean age of 61.8 years, ranging from 19 to 96 years. Most of the participants were male (68\%), married (59.2\%), had no dependents $(37.4 \%)$, had completed primary education $(34.8 \%)$, were employed (24.4\%), and had EPS (81\%). The ICU specialized in coronary heart disease had the highest number of admissions (52.9\%), with the most common being the short-stay $(3.85$ days) urgent admission (81.3\%; Table 1).

Table 1

Sociodemographic characterization of study participants

\begin{tabular}{lccc}
\hline Qualitative variables & $n$ & $\%$ & p-value \\
\hline Social security & & & 0.28 \\
Entidad promotora de salud (EPS) & 286 & 81 & \\
Medicina prepagada & 65 & 18.4 & \\
Administradora del régimen subsidiado (ARS) & 2 & 0.6 & 0.1 \\
\hline Gender & & & \\
Male & 240 & 68 & 0.45 \\
Female & 113 & 32 & \\
Marital status & & & \\
Married & 209 & 59.2 & \\
Single & 30 & 8.5 & \\
Widow & 40 & 11.3 & \\
Cohabiting & 48 & 13.6 & \\
Separated & 26 & 7.4 & \\
Profesional situation & & & \\
Homemaker & 83 & 23.5 & \\
Employed & 86 & 24.4 & \\
Independent worker & 78 & 22.1 & \\
Student & 6 & 1.7 & \\
Unemployed & 8 & 2.3 & \\
Other & 8 & 2.3 & \\
Retired & 84 & 23.8 & \\
\hline
\end{tabular}




\begin{tabular}{|c|c|c|c|}
\hline Number of dependents & & & 0.66 \\
\hline None & 132 & 37.4 & \\
\hline $1-2$ & 116 & 32.9 & \\
\hline $2-4$ & 78 & 22.1 & \\
\hline $4-6$ & 26 & 7.4 & \\
\hline More than 8 & 1 & 0.3 & \\
\hline ICU Type & & & 0.8 \\
\hline Coronary & 209 & 52.9 & \\
\hline Surgery & 107 & 30.3 & \\
\hline Medical & 9 & 2.5 & \\
\hline Type of admission & & & 0.17 \\
\hline Urgent & 287 & 81.3 & \\
\hline Planned & 64 & 18.1 & \\
\hline Other & 2 & 0.6 & \\
\hline Education level & & & 0.028 \\
\hline Primary & 123 & 34.8 & \\
\hline Secondary & 108 & 30.6 & \\
\hline University & 77 & 21.8 & \\
\hline Post-graduate & 23 & 6.5 & \\
\hline Vocational & 19 & 5.4 & \\
\hline No schooling & 3 & 0.8 & \\
\hline Quantitative variables & Mean & Standard deviation & $p$ value \\
\hline Age & 61.8 & 14.7 & $0.22^{* *}$ \\
\hline Lenght of stay (days) & 3.85 & 4.1 & $0.51^{* * *}$ \\
\hline
\end{tabular}

Note. ${ }^{*} p$-value for statistical $\mathrm{X}^{2 ; * *} p$-value for Student's t-test; ${ }^{* * *} p$-value for Mann-Whitney $\mathrm{U}$ test because this variable was not normally distributed.

In this sample, $13 \%$ of interviewees reported a moderate or high level of stress (score $\geq 91$ on the assessment scale) as opposed to the majority of the population (87\%) who considered the ICU as not stressful to a bit stressful (score $\leq 90)$. The most stressful situations were those related to: concerns about their health and its impact on their daily life (45.9\%), not being able to go to the bathroom (45.9\%), not being able to fulfill their role in the family $(41.1 \%)$, not having control over their activities (33.4\%), and feeling pain
(31.4\%). In contrast, the least stressful situations (Table 2) were the fact that men and women were hospitalized in the same room $(0.8 \%)$, the feeling that healthcare professionals pay more attention to the machines than to them $(0.8 \%)$, being pressured to accept treatments $(1.1 \%)$, using words that you do not understand $(1.4 \%)$, seeing how other patients are treated $(1.4 \%)$, and seeing that healthcare professionals do things around your bed constantly without informing you $(1.4 \%)$. 
Table 2

\section{Results from the application of the Escala de Factores Estresantes Experimentados por los Pacientes en UCI}

\begin{tabular}{|c|c|c|c|}
\hline ITEM & $\begin{array}{l}\text { POSI- } \\
\text { TION }\end{array}$ & MEAN & $\begin{array}{c}\text { STAND- } \\
\text { ARD DEVI- } \\
\text { ATION }\end{array}$ \\
\hline Tener preocupaciones por su salud y las repercusiones de esta en su vida diaria & 1 & 2.92 & 1.21 \\
\hline No poder ir al baño & 2 & 2.91 & 1.20 \\
\hline No poder cumplir con su papel en la familia & 3 & 2.62 & 1.33 \\
\hline No tener control de sus actividades & 4 & 2.61 & 1.21 \\
\hline Sentir dolor & 5 & 2.42 & 1.23 \\
\hline $\begin{array}{l}\text { No poder mover alguna parte del cuerpo por tener cables, sondas, tubos de } \\
\text { drenaje o catéteres en las venas }\end{array}$ & 6 & 2.40 & 1.31 \\
\hline Extrañar a su familia o amigos & 7 & 2.36 & 1.30 \\
\hline No poder dormir & 8 & 2.26 & 1.28 \\
\hline $\begin{array}{l}\text { Escuchar frecuentemente sonidos inusuales y/o desconocidos hechos por las } \\
\text { máquinas que hay a su alrededor }\end{array}$ & 9 & 2.11 & 1.23 \\
\hline Ser pinchado con agujas & 10 & 2.09 & 1.24 \\
\hline No tener privacidad & 11 & 2.08 & 1.23 \\
\hline No saber cuánto tiempo va a estar en cuidados intensivos & 12 & 1.93 & 1.23 \\
\hline No saber qué hora es & 13 & 1.84 & 1.19 \\
\hline Sentirse aburrido & 14 & 1.82 & 1.16 \\
\hline Tener luces a su alrededor permanentemente encendidas & 15 & 1.80 & 1.17 \\
\hline Tener miedo de morir & 16 & 1.78 & 1.21 \\
\hline Tener que usar para su tratamiento tubos o máscaras en la nariz y/o en la boca & 17 & 1.68 & 1.16 \\
\hline Que su tensión arterial sea tomada con mucha frecuencia & 18 & 1.62 & 1.01 \\
\hline Ser despertado por las personas del hospital que lo atienden & 19 & 1.59 & 0.97 \\
\hline Tener sed, no poder expresarla y/ o calmarla & 20 & 1.56 & 1.14 \\
\hline Escuchar a otros pacientes gritar o quejarse & 21 & 1.53 & 1.18 \\
\hline Por la posición de su cuerpo ver siempre lo mismo & 22 & 1.44 & 0.91 \\
\hline Sentirse incómodo por la almohada o cama & 23 & 1.40 & 0.93 \\
\hline No poder comunicarse & 24 & 1.36 & 1.05 \\
\hline Ser examinado en muchas ocasiones & 25 & 1.27 & 0.77 \\
\hline Estar rodeado por máquinas extrańas & 26 & 1.25 & 0.78 \\
\hline Tener hambre y no poder expresarla y/o calmarla & 27 & 1.22 & 0.86 \\
\hline Estar en una habitación que es demasiado caliente o fría & 28 & 1.20 & 0.82 \\
\hline Desconocer el nombre de las personas que lo atienden y que estas no lo saluden & 29 & 1.17 & 0.68 \\
\hline No saber qué día es & 30 & 1.17 & 0.87 \\
\hline Sentir que el personal que lo atiende no tiene suficiente tiempo para su cuidado & 31 & 1.16 & 0.84 \\
\hline Escuchar a las personas hablar sobre usted & 32 & 1.14 & 0.72 \\
\hline No saber dónde está & 33 & 1.14 & 1.02 \\
\hline Sentir temor de contagiarse de enfermedades dentro del hospital & 34 & 1.10 & 1.03 \\
\hline Ser cuidado por personas desconocidas & 35 & 1.08 & 0.71 \\
\hline Percibir olores raros a su alrededor & 36 & 1.03 & 0.61 \\
\hline Sentir que el personal que lo atiende habla con un tono de voz demasiado fuerte & 37 & 1.01 & 0.73 \\
\hline Que se utilicen palabras que usted no entiende & 38 & 1.01 & 0.64 \\
\hline Saber o ver que algún paciente fallece & 39 & 0.97 & 0.69 \\
\hline $\begin{array}{l}\text { No tener explicación de los procedimientos que a usted le hacen como parte } \\
\text { de su tratamiento }\end{array}$ & 40 & 0.96 & 0.68 \\
\hline $\begin{array}{l}\text { Sentir que las personas que lo atienden prestan más atención a las máquinas } \\
\text { que hay a su alrededor que a usted }\end{array}$ & 41 & 0.94 & 0.62 \\
\hline Ser presionado para aceptar la realización de tratamientos & 42 & 0.93 & 0.58 \\
\hline $\begin{array}{l}\text { Que el personal que lo atiende haga cosas alrededor de su cama constante- } \\
\text { mente sin informarle }\end{array}$ & 43 & 0.90 & 0.57 \\
\hline Ver cómo se realizan tratamientos a otros pacientes & 44 & 0.90 & 0.66 \\
\hline Estar hombres y mujeres hospitalizados en el mismo espacio & 45 & 0.82 & 0.62 \\
\hline
\end{tabular}


A bivariate analysis was performed on the sociodemographic characteristics and the stressors included in the scale. A statistical significance was found between education ( $p$ $=0.028)$ and item $31(p=0.040)$ : feeling that nurses are in too much of a hurry, which suggested that these factors are associated with stress at the ICU. Based on these findings, a multivariate analysis was performed using a binary logistic regression. The results
(Table 3) confirmed the statistical significance between basic $(p=0.028, O R=16)$ and university education $(p=0.027, O R=17)$, with a Wald of 4.85 - 4.87 Wald, respectively. Item 31 had no statistical significance in the assessed model. Therefore, it can be concluded that a low education level such as basic education or a vocational education influenced the perception of stressors and stress in the group under analysis.

Table 3

Logistic Model

\begin{tabular}{llllll}
\hline \multicolumn{1}{l}{ Equation Variables } & & & & \\
\hline \multirow{5}{*}{ Education } & $\mathrm{B}$ & Wald & $p$ value & \multirow{2}{*}{$O R$} \\
\hline & Basic education & 2.776 & 4.857 & 0.028 & 16.052 \\
\cline { 2 - 6 } & Secondary education & 2.351 & 3.511 & 0.061 & 10.500 \\
\cline { 2 - 6 } $1^{\text {st step }}$ & University education & 2.846 & 4.879 & 0.027 & 17.223 \\
\cline { 2 - 6 } & Postgraduate degree & 2.462 & 3.208 & 0.073 & 11.728 \\
\cline { 2 - 6 } & Vocational & 1.543 & 1.333 & 0.248 & 4.677 \\
\cline { 2 - 6 } & Item 31 & 1.750 & 2.861 & 0.091 & 5.754 \\
\cline { 2 - 6 } & Constant & -0.693 & 0.320 & 0.571 & 0.500 \\
\hline
\end{tabular}

\section{Discussion}

Contrary to what would be expected, most of the patients assessed their stay at the ICU as being a bit stressful or not stressful at all. This result is similar to those found in the studies carried out by Soh, Soh, Ahmad, Abdul Raman, and Japar (2008), Fernandes da Cruz, Machado, Fernandes da Cruz, and Salazar Posso (2013) which found no high levels of stress. This result confirms that there are no universally stressful events, they only exist when a person defines them as such. Therefore, the amount of stress will depend on the adequacy between environmental demands, the available resources, and the way in which the patient interacts and responds to external phenomena, as it is suggested by Lazarus and Folkman's Transactional Model.

These results could also be explained by the ICU patients' evaluation because many of them reported that the situations experienced at the ICU were protective, beneficial, and necessary to preserve life, regardless of the degree of threat that they posed. When faced with life or death and/or recovery from a delicate health status, interviewees tolerated nudity, family absence, pain, discomfort, loneliness, and boredom.

In the population under analysis, there was a predominance of men, who are characterized for having more difficulty in expressing feelings (Borraz-Léon, Herrera-Pérez, Cerda-Molin, \& Martínez-Mota, 2015) or being less willing to discuss their concerns.

Shorter ICU stays limit the exposure to the ICU environment and influence ICU perception. Badia-Castelló, Trujillano-Cabello, Serviá-Goixart, March-Llanes, and Rodríguez-Pozo (2006) found that when patients stay fewer days at the ICU, they do not build memories or their memory is not illusory. However, spending more days at the hospital increases the likelihood of building illusory memories, such as hallucinations, nightmares, or thinking that people want to harm them.

The degree of complexity of care that limits the number of stressors (Dias, Resende, \& Diniz, 2015), because, in a consistent way with the main causes of morbidity and mor- 
tality worldwide, the unit from which most data were obtained was the coronary ICU, which is specialized in cardiovascular problems and provides intermediate care. For this reason, monitoring, therapeutic measures, and life support are less aggressive and invasive; hence, our study contradicts other studies where there is a preponderance of physical factors such as thirst, not being able to sleep, restraint, limitation of movement, and having tubes in the nose or mouth (Bernal Ruiz \& González Consuegra, 2015).

Additionally, we believe that the exceptional provisions and norms of the ICU where the study was conducted were essential for these findings because: 1 . The rooms were single-bed rooms which allow for more privacy, soundproof, and there was little contact with other patients; 2. The lighting was mostly natural and artificial lighting was adjusted to day/night cycles. A clock was visible and each room had a television. These measures promote distraction and improve sleep quality and time-space orientation; 3. Concrete and simple measures are required to improve care humanization and adaptation to the critical situation, such as care protocols for patient treatment, informed consent for activities, and standards for a continuous, explicit, and clear communication about the health-disease process. Therefore, the patients' previous preparation to be admitted to the ICU (planned admission) or their capacity to pay for their stay (EPS, ARL, prepaid medicine) make no difference; 4 . There was a flexible, adjustable visiting schedule, which provided continuous emotional contact with the spouse (the most common marital status)/ family/friends, strengthening the protective role of the family against stress (Escudero, Viña, \& Calleja, 2014).

With regard to nursing, a positive emphasis is placed on the nurse-patient relationship: 1:31:4 and the assistant nurse-patient relationship: 1:2 - 1:3 (adjustable to the severity of the conditions), which facilitates individualized care and ensures less workload, resulting in a timely, safe, and high-quality delivery of care. We assume, therefore, that it is very important for patients to feel that the healthcare professional caring for them does not have enough time for care delivery because work is always focused on them. In this sample, the most stressful situations were those associated with psychological factors, particularly pain and autonomy. This may reflect, on the one hand, the dissemination or awareness of the right of all human beings not to feel pain and, on the other hand, of subjects whose age and occupation make them self-sufficient, as well as economically, politically, and socially active.

In general, pain and lack of self-control are recurrent stressors and have been long been recognized (Bernal Ruiz \& González Consuegra, 2015), which should make us reflect on the interventions being done to manage them because we are clearly being ineffective in transforming easily modifiable factors. An explanation for this might be what Biancofiore et al. (2005) have called an underestimation of factors over which there is some type of control or for which there is a wide range of therapeutic options; the emphasis on situations on which one's own needs or fears are projected; the mechanization of work because healthcare professionals are adapted to the ICU environment and forget that everything is new for the patient; or the paternalistic relationship of professionals that leads to submission and eliminates people's independence. For this reason, in today's world, more and more practices are advocating the correct and timely evaluation and treatment of pain (Sakata, 2010), as well as the respect for autonomy (Arias Garrido, 2012).

The association between the education level and the level of stress should be highlighted. We believe that this finding is based on the opportunity provided by education to gain knowledge and understanding of the health phenomena. A high education level expands the cognitive aspects of the health-disease process, which can promote the early interpretation of the situations experienced. On the other hand, a low level of education overwhelms people with ignorance and uncertainty about their disease experiences.

\section{Conclusion}

Most interviewees considered their stay at the ICU as not stressful or mildly stressful. Based on the Escala de Factores Estresantes Experimentados por los Pacientes en UCI, the most 
stressful situations for patients were emotional situations and those associated with loss of control and pain. A high or a low education level influences the perception of stress.

Therefore, during ICU stay, it is important to empower patients and engage them in their own care plan. Simple self-care and health promotion tasks can be designed in collaboration with the care team to meet patients' wishes and maintain their autonomy taking into account the complexity of their health status. It is also important to re-evaluate the clinical practices related to pain assessment/ management, as well as individual strategies for patient care depending on their education level. With regard to the academy, it is essential to create spaces for reflection aimed at designing processes for the transformation of ICU care practices. We cannot afford to perpetuate errors which are already known and have long been identified in care delivery. The knowledge about patients' experiences should encourage us to develop attitudes, skills, and activities aimed at promoting positive and satisfying experiences.

Since this is the first study using the Escala de Factores Estresantes Experimentados por los Pacientes en UCI, it would be important to compare these findings with those obtained in another sample with other care conditions given the peculiarities of critical care in the institutions where the study was carried out.

\section{References}

Arias Garrido, J. J. (2012). ¿Cómo determinar la competencia del paciente crítico? Cada vez más cerca de la solución. Medicina Intensiva, 36(6), 387-388. Retrieved from http://scielo.isciii.es/scielo.php?script=sci_arttext\&pid=S0210-56912012000600002\&lng=es. http://dx.doi.org/10.1016/j.medin.2011.12.003.

Badia-Castelló, M., Trujillano-Cabello, J., Serviá-Goixart, L., March-Llanes, J., \& Rodríguez-Pozo, A. (2006). Recuerdos y memoria del paciente crítico a largo plazo. Desarrollo de estrés postraumático. Medicina Clinica, 126(15), 561- 566. doi: 10.1157/13087690

Baggio, M. A., Pommatti, D. M., Bettinelli, L. A., \& Erdmann, A. L. (2011). Privacidade em unidades de terapia intensiva: direitos do paciente e implicaçóes para a enfermagem. Revista Brasileira de Enfermagem, 64(1), 25-35. Retrieved from https://dx.doi.org/10.1590/ S0034-71672011000100004

Bernal Ruiz, D. C., \& González Consuegra, R. V. (2015). Instrumentos de medición de factores estresantes que afectan las personas en cuidado intensivo: revisión integrativa. Evidentia, 12(50). Retrieved from http:// www.index-f.com/evidentia/n50/ev9511.php

Bernal Ruiz, D. C., \& González Consuegra, R. V. (2016). Adaptación transcultural, validez y confiabilidad del Environmental Stress Questionnaire. Revista Cubana de Enfermeria, 32(2), 182-195. Retrieved from http://scielo.sld.cu/scielo.php?script=sci_arttext\&pid=S0864-03192016000200005\&lng=es

Biancofiore, G., Bindi, M. L., Romanelli, A. M., Urbani, L., Mosca, F., \& Filipponi, F. (2005). Stress-Inducing Factors in ICUs: What Liver Transplant Recipients Experience and What Caregivers Perceive. Liver Transplantation, 11(8), 967-972. doi: 10.1002/lt.20515.

Borráz-León, J. I., Herrera-Pérez, J. J., Cerda-Molina, A. L., \& Martínez-Mota, L. (2015). Testosterona y salud mental: una revisión. Psiquiatría Biológica, 22(2), 4449. doi: 0.1016/j.psiq.2015.10.005

Chamorro, C. \& Romera, M. A. (2015). Dolor y miedo en la UCI. Medicina Intensiva, 39(7), 442-444. doi: 10.1016/j.medin.2015.05.005

Dias, D. S., Resende, M. V., \& Diniz, G. C. (2015). Estresse do paciente na terapia intensiva: comparação entre unidade coronariana e pós-operatória geral. Revista Brasileira de Terapia Intensiva, 27(1), 18-25. doi: 10.5935/0103-507X.20150005.

Elliott, D., Davidson, J. E., Harvey, M. A., Bemis-Dougherty, A., Hopkins, R. O., Iwashyna, T. J., \& Needham, D. M. (2014). Exploring the scope of post-intensive care syndrome therapy and care: engagement of non-critical care providers and survivors in a second stakeholders meeting. Critical Care Medicine, 42(12), 2518-2526. doi: 10.1097/ CCM.0000000000000525

Escudero, D., Viña, L., \& Calleja, C. (2014). Por una UCI de puertas abiertas, más confortable y humana. Es tiempo de cambio. Medicina Intensiva, 38(6), 371375. doi: 10.1016/j.medin.2014.01.005

Fernandes da Cruz, S. L., Machado, R. C., Fernandes da Cruz, S. V., \& Salazar Posso, M. B. (2013). Estrés del paciente en UCI: visión de los pacientes y del equipo de enfermería. Enfermería global, 12(32), 88-103. Retrieved from http://scielo.isciii.es/scielo.php?script=sci_ arttext\&pid=S1695-61412013000400006\&lng=es.

Guttormson, J. L. (2014). Releasing a lot of poisons from my mind: patients delusional memories of intensive care. Heart Lung, 43(5), 427-341. doi:10.1016/j.hrtlng.2014.04.007.

Jutte, J. E., Erb, C. T. \& Jackson J. C. (2015). Physical, Cognitive, and Psychological Disability Following Critical Illness: What Is the Risk?. Seminars in Respiratory and Critical Care Medicine, 36(6), 943-58. doi: 10.1055/s-0035-1566002.

Olausson, S., Lindahl, B., \& Ekebergh M. (2013). A phenomenological study of experiences of being cared for in a critical care setting: the meanings of the patient room as a place of care. Intensive Critical Care Nurse, 29(4), 234-243. doi: 10.1016/j.iccn.2013.02.002. 
Orlandini, A. (1999). Estresor: Definición y clasificación: El Estrés: Qué es y Cómo evitarlo (2d, pp. 18 - 30). Argentina.

Parker, A. M., Sricharoenchai, T., Raparla, S., Schneck, K. W., Bienvenu, O. J., \& Needham, D. M. (2015). Posttraumatic stress disorder in critical illness survivors: a metaanalysis. Critical Care Medicine, 43(5), 11211129. doi: 10.1097/CCM.0000000000000882.

Rom, O. \& Reznick, A. Z. (2016). The Stress Reaction: A Historical Perspective. Advances in Ex- perimental Medicine and Biology, 905, 1-4. doi: 10.1007/5584_2015_195.

Sakata, R. K. (2010). Analgesia y sedación en unidad de cuidados intensivos. Revista Brasileira de Anestesiologia, 60(6), 360 - 365. Retrieved from http://dx.doi. org/10.1590/S0034-70942010000600012

Soh, K. L., Soh, K. G., Ahmad, Z., Abdul Raman, R., \& Japar, S. (2008). Perception of Intensive Care Unit stressors by patients in Malaysian Federal Territory hospitals. Contemporary Nurse, 31(1), 86-93. 